\title{
Pulmonary function testing in the Emergency Department and medications prescribed at discharge: results of the Multinational Acute asthma Management, Burden, and Outcomes (MAMBO) study
}

\section{*J Mark Fitzgeralda, Paul M O'Byrne ${ }^{b}$, Jeffrey T McFetridgec, Dirk Demuth ${ }^{\text {, }}$ Felicia C Allen-Ramey}

a Professor of Medicine, University of British Columbia (UBC), and Head, UBC and Vancouver General Hospital (VGH) Division of Respiratory Medicine, The Lung Centre, Gordon and Leslie Diamond Health Care Centre; and Director, Centre for Lung Health, University of British Columbia, Vancouver, BC, Canada

${ }^{b}$ Firestone Institute for Respiratory Health, St. Josephs Hospital, and the Department of M edicine, M cMaster University, Hamilton, Ontario, Canada

Department of Economics, Lehigh University, Bethlehem, PA, USA

d Adelphi Real World, Bollington, UK

e Global Outcomes Research, Merck \& Co., Inc., Whitehouse Station, NJ, USA.

Received 6th May 2009; resubmitted 1st October 2009; revised 17th November 2009; accepted 27th December 2009; online 26th January 2010

\begin{abstract}
Aims: To evaluate asthma care in the emergency department (ED), including use of pulmonary function testing (PFT) and how patients are treated when discharged.

Methods: Internet-based surveys were completed by 298 healthcare practitioners in seven countries on 1078 patients 15-70 years old with an acute asthma exacerbation.

Results: Less than $60 \%$ of patients received guideline-recommended therapy with a bronchodilator, corticosteroid, and supplemental oxygen. Patients undergoing PFT had significantly more courses of asthma therapy ( 2.3 vs $1.7 ; p<0.001)$, and received more medications (5.7 vs 3.9; $p<0.001)$. At discharge, $17.9 \%$ of patients did not receive a prescription asthma medication and $12.8 \%$ did not receive a physician referral. Men $(p<0.022)$, patients with more severe disease $(p<0.0001)$, and those seen by a pulmonologist $(p<0.0001)$, were more likely to be treated.

Conclusions: Management of patients with acute asthma exacerbations diverged from guideline recommendations. Enhanced adherence to guidelines could lead to improved outcomes.

(C) 2010 Primary Care Respiratory Society UK. All rights reserved.

JM Fitzgerald et al. Prim Care Resp J 2010; 19(2): 155-162

doi:10.4104/pcrj.2010.00005
\end{abstract}

Keywords asthma, exacerbation, guidelines, disease severity, treatment outcomes, assessment, drug therapy, emergency department, lung function

The full version of this paper, with online Appendix,

is available at www.thepcrj.org

\section{Introduction}

Asthma is a chronic condition often associated with acute exacerbations, especially when not well controlled. Acute asthma often necessitates care in the emergency department (ED) and may be life-threatening. ${ }^{1-4}$ Acute asthma affects $10 \%$ of patients with asthma in Western Europe and $23 \%$ of those with asthma in the US, annually. ED visits not only make a

\footnotetext{
* Corresponding author: Professor J Mark Fitzgerald, Professor of Medicine, Head, UBC and VGH Division of Respiratory Medicine, The Lung Centre, 7th Floor, Gordon and Leslie Diamond Health Care Centre, 2775 Laurel Street, Vancouver, BC V5Z $1 \mathrm{M} 9$ Canada

Tel: 604-875-4122 Fax: 604-875-4695 E-mail: markf@interchange.ubc.ca
} 
substantial contribution to healthcare costs worldwide, but are also markers of increased morbidity, along with suboptimal access to care, treatment adherence, and/or selfmanagement. ${ }^{5-10}$ Effective guideline-driven management of diagnostic testing in the ED and prescription of asthma controller medications upon ED discharge could decrease the need for urgent care.

Asthma treatment guidelines issued by the Global Initiative for Asthma (GINA) and other consensus panels state that objective pulmonary function testing (PFT) plays a central role in evaluating and managing acute asthma exacerbations. ${ }^{11-17}$ GINA guidelines specify that functional assessments such as spirometry, peak expiratory flow (PEF) measurement, and oxygen saturation measurements with oximetry, to assess the severity of an asthma exacerbation, should be performed ideally prior to, but hopefully concurrently with, any intervention instituted in the ED. Such assessments should be repeated one hour after initial treatment and then at 1- to 2-hour intervals until there is a clear response to treatment and a decision is reached about patient disposition. " GINA guidelines recommend that the care of patients discharged with an acute asthma attack should generally include: 1) a minimum 3- to 7-day course of oral corticosteroids; 2 ) initial or continued use of controller therapy; 3) review of inhaler technique and use of peak flow meter; 4) identification of potential triggers of exacerbations; 5) provision of a written action plan for prevention of future exacerbations; and 6) encouragement to contact a physician within one week after discharge for a follow-up appointment. ${ }^{11}$

Treatment programs that adhere to asthma management guidelines and a high continuity of care can significantly reduce ED visits, ${ }^{15,17}$ yet information on guideline adherence to PFT and prescribing practices for acute asthma exacerbations in the ED is limited. The aim of the Multinational Acute asthma Management, Burden, and Outcomes (MAMBO) study was to understand current approaches to acute asthma care in the ED around the world. This manuscript describes the frequency with which PFT was performed, along with the asthma treatment prescribed for patients upon ED discharge.

\section{Methods}

\section{Study design}

The MAMBO study was a multinational, Internet-based observational survey of acute asthma care conducted in Australia, Canada, Mexico, Italy, France, Spain, and the UK. This study was solely an audit of patient chart records undertaken by the treating physician, and was not experimental or interventional. Data were captured in an anonymised form, and thus Institutional Review Board approval was not required. The study did not require ethics approval because it was designed to describe the standard approach to care for acute asthma in the ED, and there were no confidentiality issues identified given the non-nominal nature of the data entry.

\section{Study population}

Healthcare practitioners (HCPs) who treated $\geq 10$ patients with asthma per year in the ED and who were not currently involved in any clinical trials for asthma were eligible for participation. HCPs were identified and recruited from a worldwide panel of physicians who had previously expressed interest in participating in asthma research; the panel represented different types of physician based in different countries and regions within those countries. Physicians were recruited through clinical websites and other methods operated by our Internet service provider to select physicians interested in market research; identities were validated. Approximately 4,000 eligible physicians were identified and invited to participate in this study.

A feasibility assessment focused on the ability to collect the desired patient data was conducted during the initial planning phase of the study (primarily via interview with a few HCPs from each country). The original patient target number of approx 1200 total patients (approx 170 per country) from 42 HCPs per country was determined appropriate for statistical testing of differences across countries. These numbers were exceeded and data were collected on 1,370 patients, since most physicians elected to provide data on more than the minimum number of patients requested. The pre-specified target numbers were met over a 6.5 week period. HCPs were remunerated for their participation in the survey.

Respondents provided information extracted from the medical records of the most recent four to six consecutive, unique patients they had treated for acute asthma who met the study inclusion criteria; patients were aged 15-70 years old and were treated in the ED for a primary diagnosis of an acute asthma exacerbation from January 1st to December 31st, 2006. Patients with a primary diagnosis of chronic obstructive pulmonary disease (COPD), bronchiectasis, bronchiolitis, cystic fibrosis, lung cancer, pneumonia, or other airway infections were excluded.

\section{Survey instrument}

The survey instrument (see online Appendix at www.thepcrj.org) was developed by Adelphi Real World (Bollington, UK), a global health-services research group. It was translated into the primary language(s) of each country, then back-translated into English for tabulation and analysis. The instrument was tested before the study started to ensure reliability (routing, completeness). Final routing (i.e. when a respondent answers a question and is routed to the next applicable question), validation and consistency checks were 
conducted to ensure data were within range and routed to the correct field. A secure Internet website was established for uploading of data. To ensure the quality of the data, internal validation checks were written into the survey programme (e.g. acceptable drug doses, values for clinical results, etc). Similar approaches utilising electronic data capture have been reported for other published studies. ${ }^{18-20}$

Participating HCPs entered information directly into the survey instrument. Patient data included demographic and clinical information, such as physician-assessed asthma severity, the presence of co-morbidities, prescription medications self-administered within 24 hours before presentation to the ED, and mode of arrival. Patient outcomes examined were receipt of certain prescribed medications/referrals upon discharge from the ED setting by country and by history of self-administering these medications within 24 hours of presenting to the ED. All data were made anonymous and age bands rather than dates of birth recorded to prevent patient identification.

Continuous data monitoring revealed the need for slight modification of the survey instrument during the early stages of data collection. Invalid values submitted for a question on asthma admission codes, intended to signify severity of the exacerbation, indicated a misinterpretation of the question and need for adjustment. The initial question was rewritten to solicit the physician-perceived severity of the exacerbation. As a result, the severity of the exacerbation for data reported prior to the modification could not be obtained and patients were reported as unclassified.

\section{Statistical analysis}

Patients with a secondary diagnosis of COPD or those who spent $>12$ hours in the ED were excluded. Descriptive data were summarised as mean (SD), or in box-whisker plots, and categorical data as number (\%). Categorical data between countries and patients receiving (versus not receiving) PFT were compared using Fisher's exact tests and $\chi^{2}$ tests; continuous data were compared using Student's $t$ tests. Statistical testing was two-sided at $\alpha=.05$. Analyses were conducted using STATA 9.2 Special Edition (StataCorp, College Station, TX).

\section{Results}

Data from 1,078 patients seen by 298 HCPs were analysed. Most HCPs were men (78\%) based in urban hospitals (91\%) who earned their academic degrees from 1980-1999 (74\%). ED physicians comprised $30.9 \%$ of all HCPs $(37.8 \%$ of HCPs in France), pulmonologists comprised $30.9 \%$ (36.8\% in Italy), and internists comprised $30.2 \%$ (34.9\% in Mexico). In most countries, the major specialties of the HCPs were ED physicians (range: $22.7 \%$ of HCPs in Australia to $37.8 \%$ in France), pulmonologists $(22.7 \%$ in Australia to $36.8 \%$ in Italy), or internists (22.7\% in Australia to $34.9 \%$ in Mexico).

Approximately $50 \%$ of patients had mild or moderate exacerbations by physician assessments; $54 \%$ of patients were female; and 39\% were smokers (see Table 1).

\section{Pulmonary function testing (PFT)}

Fewer than half ( $n=527,49 \%)$ of the patients underwent objective measurement of airflow obstruction in the ED, with

Table 1. Patient characteristics by country.

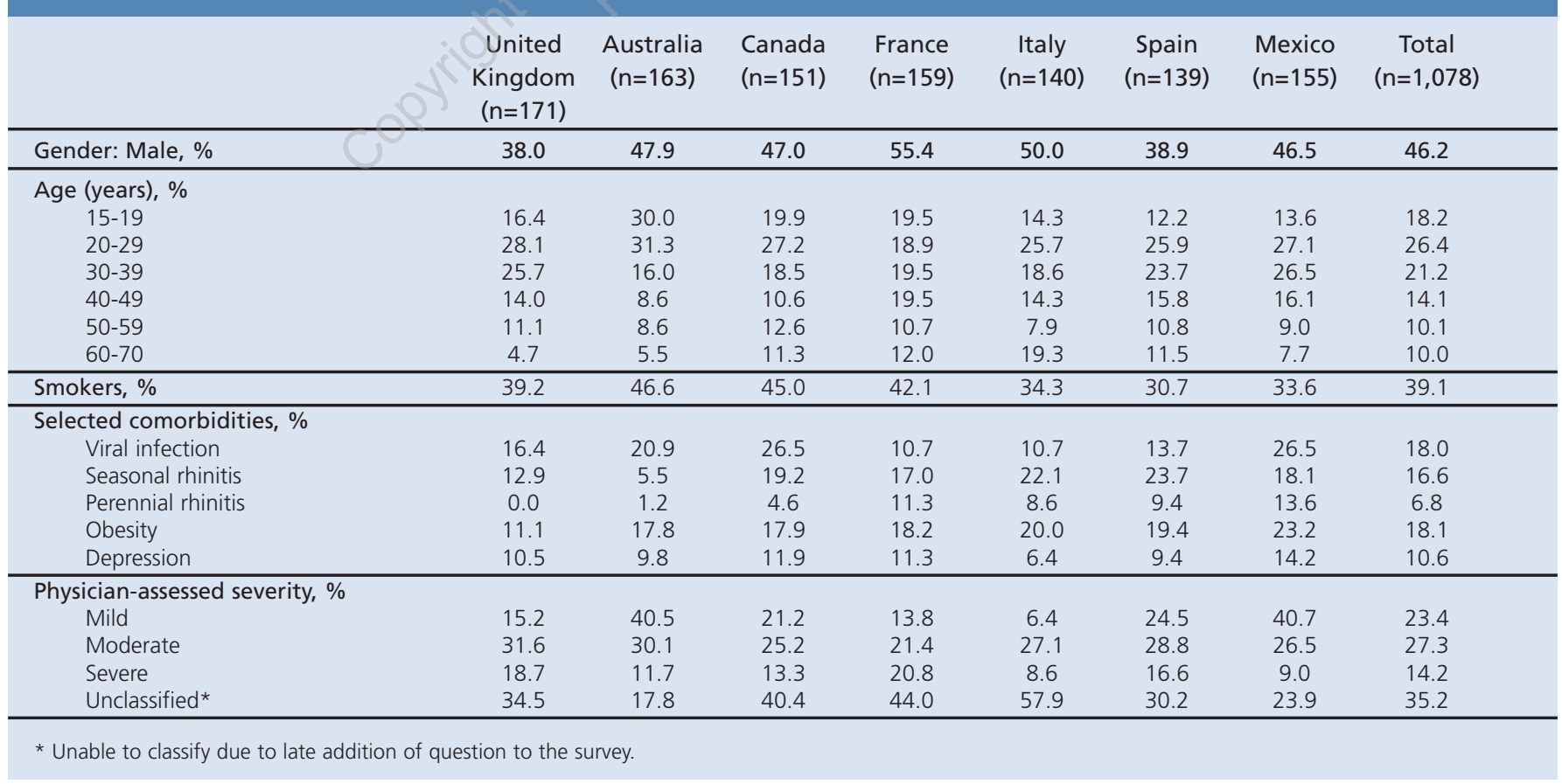


JM Fitzgerald et al.

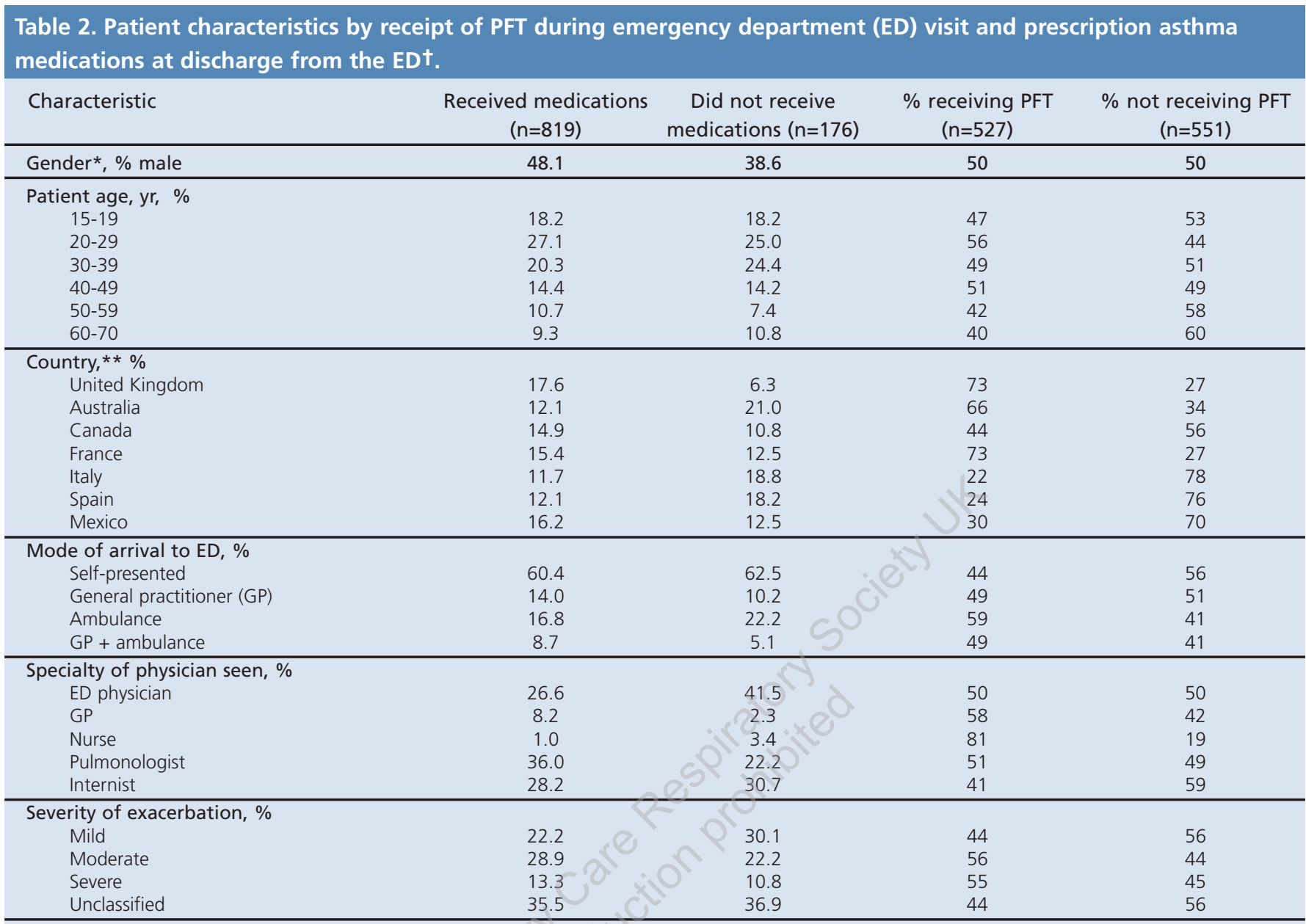

†Eighty-three patients did not have information on medications prescribed at discharge from the ED.

${ }^{*} p=0.022 ;{ }^{* *} p<0.0001$. Derived from chi-square test of differences among patients receiving (vs not receiving) prescription antiasthma medications at ED discharge.

wide variation across countries (see Table 2 and Figure 1). Lung function was less commonly assessed in Mexico, Spain, and Italy, and more commonly assessed in Australia, the UK, and France. Among patients who had PFT, $77 \%$ had a PEF measured, $11 \%$ an $\mathrm{FEV}_{1}$, and $12 \%$ had both PEF and $\mathrm{FEV}_{1}$ measured. Patients who completed PFT were significantly more likely to have pulse oximetry (Table 2 ). Nearly half $(44 \%)$ of patients with moderate or severe exacerbations did not undergo PFT. Patients were more likely to have PFT if they arrived by ambulance (59\%) as opposed to self-presenting (44\%). Younger patients aged 20-29 years were more likely to undergo PFT than those 50-70 years old. Patients were more likely to undergo PFT in academic centres (57\%) compared with community $(29 \%)$ or regional hospitals $(5 \%)$. HCPs who ordered PFT were most likely to work in large hospitals with $501-1,000$ beds (42\%). Male HCPs were more likely than their female counterparts to order PFT for all of their patients $(70 \%$ vs $30 \%$ ). Male HCPs ordered PFT for $134 / 228$ patients, while female HCPs ordered PFT for 393/850 patients $(p<0.001)$.

Patients who had PFT completed significantly more courses
Figure 1. Proportions of patients receiving pulmonary function testing (PFT) by country. ${ }^{1}$

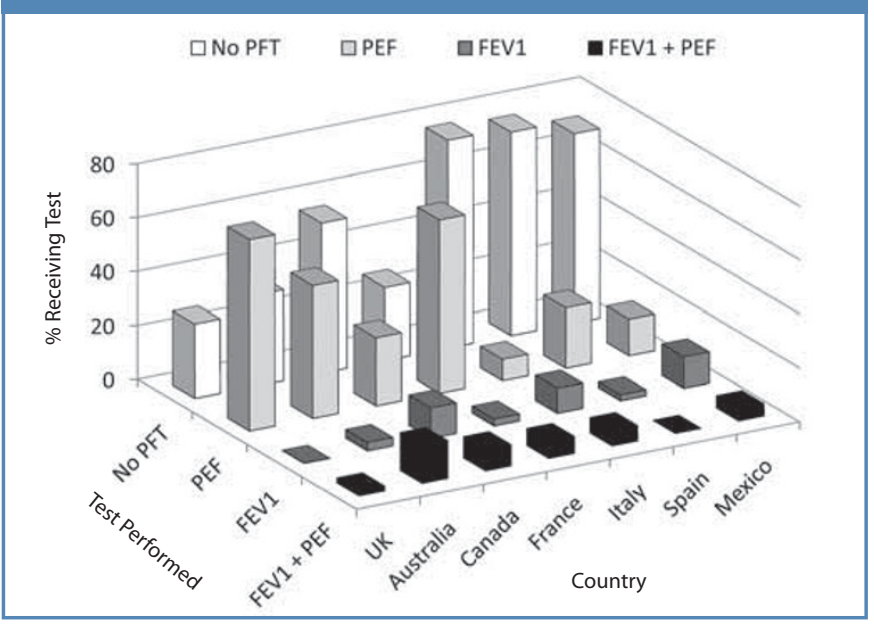

of asthma therapy, (mean [SD]: 2.3 [1.3] vs 1.7 [1.1]; $\mathrm{p}<0.0001)$, and received significantly more total medications (mean [SD]: 5.7 [3.9] vs 3.9 [3.1]; $p<0.0001$ ), in the ED. This 
difference was significant in Mexico, Australia, Canada, and France. Patients undergoing PFT spent significantly more time in the ED (mean [SD]: 4.2 [2.9] hours vs 3.7 [2.7] hours; $\mathrm{p}<0.005)$; this was true in all countries except Spain.

Patients who completed PFT were more likely to receive a combination of asthma treatments compared with monotherapy (chiefly $\beta$-agonists), and were less likely to receive no asthma medications. Less than $60 \%$ of all patients received guideline-recommended ED therapy consisting of a bronchodilator, corticosteroid (oral or inhaled), and supplemental oxygen (59\% PFT vs $45 \%$ no PFT; $p<0.001$ ). Similar trends were evident for patients receiving a bronchodilator (95\% PFT vs $90 \%$ no PFT; $\mathrm{p}<0.001$ ), or a bronchodilator plus a corticosteroid ( $81 \%$ PFT vs $72 \%$ no PFT; $\mathrm{p}<0.001)$.

Patients who were hospitalised were more likely to have received PFT (35\% vs $29 \% ; \mathrm{p}=0.039$ ) (Figure 2). A total of $17 \%$ of patients without PFT were discharged to the community without referral to a specialist, compared with $9 \%$ of those who had received PFT $(p<0.0001)$.

\section{Discharge medications}

Survey data were obtained on the type of medications taken within 24 hours before presentation to the ED, as reported by

\section{Figure 2. Patient outcomes in patients by pulmonary function testing (PFT)t.}

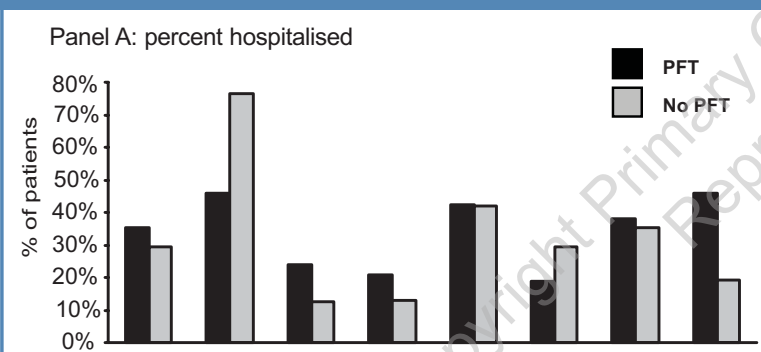

Panel B: percent discharged from the ED with a referral to a specialist

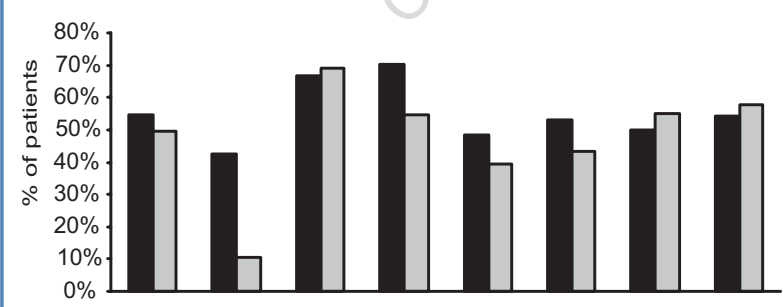

Panel C: percent discharged from the ED without a referral to a specialist

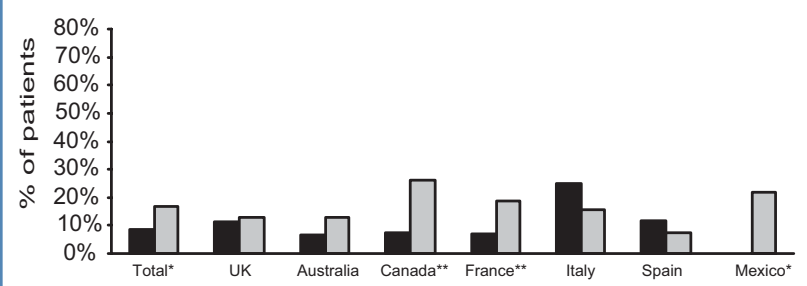

†A small number of patients either died in the ED (PFT 0.4\%; no PFT 1.5\%) or had unknown destinations (PFT 1.1\%; no PFT 2.7\%); ${ }^{*} p<0.0001,{ }^{* *} p<0.05$ for PFT vs no PFT. patients. A total of 549 (50.9\%) patients self-administered prescription asthma medications before presenting to the ED. Of these, 74\% used short-acting $\beta$-agonist (SABA) "rescue" agents; 30\% inhaled corticosteroids (ICS) monotherapy; $22.0 \%$ a combination of ICS and long-acting $\beta$-adrenergic agonist (ICS/LABAs); 18.2\% anti-cholinergics; $13.7 \%$ LABAs alone; and $13.1 \%$ oral corticosteroids. Other therapies included theophylline and leukotriene receptor antagonists (LTRAs) in approximately $4 \%$ of patients and supplemental oxygen in $<1 \%$ (many patients used more than one therapy). The proportions of patients using $\beta$-agonists ranged from $75.8 \%$ in Italy to $100 \%$ in France, self-administered ICS ranged from $33.3 \%$ in Mexico to $64.8 \%$ in Canada, and oral corticosteroids ranged from $6.6 \%$ in Canada to $21.0 \%$ in Italy. The proportions of patients using each of these medication classes at or before ED presentation were evenly distributed by asthma severity. Information on previous medication use was unavailable in 102 (9.5\%) patients.

A total of $176(17.7 \%)$ of 995 patients with available data did not receive a prescription for an asthma medication upon discharge from the ED (Table 2), ranging from $6.3 \%$ in the UK to $21.0 \%$ in Australia. Patients who did receive discharge medications were significantly more likely to be male $(p=0.02)$, to have more severe disease based upon physician assessment of severity $(p<0.0001)$, and to have been seen by a pulmonologist/chest physician rather than an ED physician $(p<0.0001)$.

Of all patients discharged with a prescription for asthma medication, $73.7 \%$ received a controller agent, including ICS, ICS/LABA, and/or LTRAs. Country-specific proportions ranged from $60.9 \%$ of patients in Mexico to $83.4 \%$ in Italy (Figure 3). Corresponding data for other medications included a reliever

Figure 3. Proportions of patients receiving prescribed asthma medications at discharge from the emergency department (ED), by countryt.

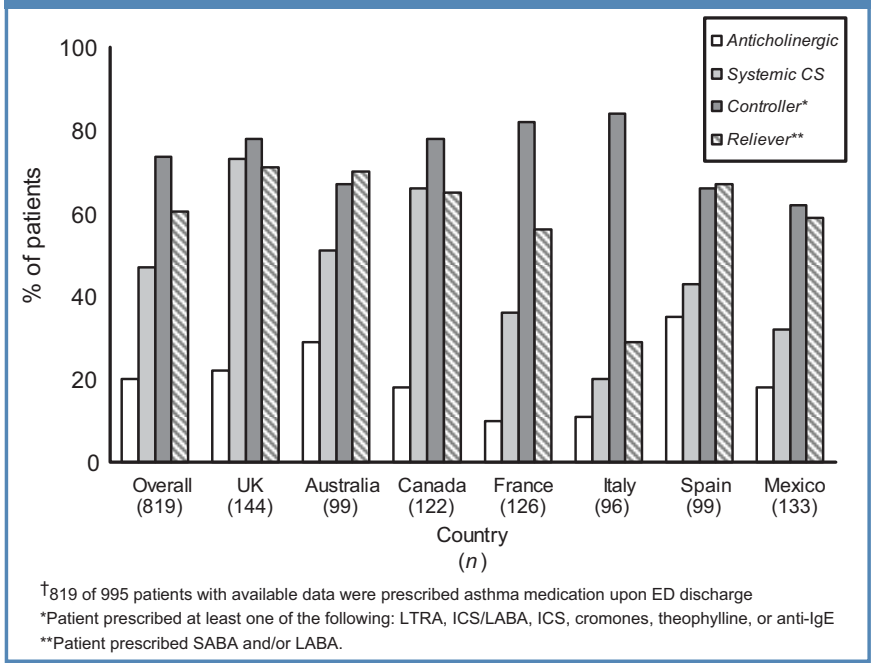




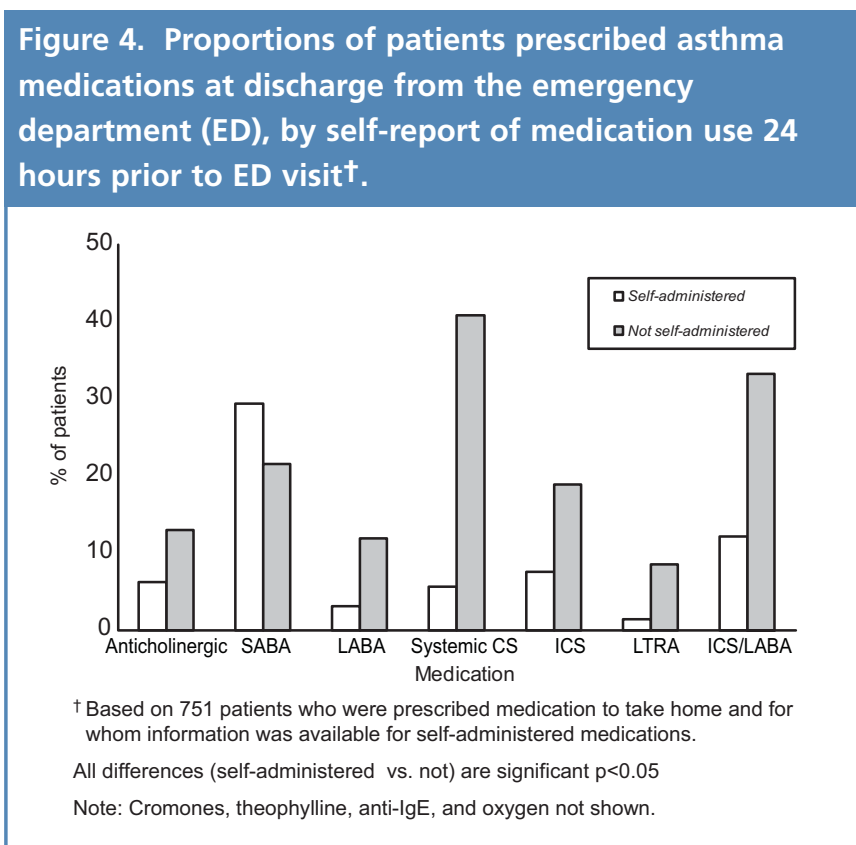

medication prescribed to $60.4 \%$ of patients, $29.2 \%$ in Italy to $71.5 \%$ in the UK), $46.9 \%$ receiving oral corticosteroids $(19.7 \%$ in Italy to $72.9 \%$ in the UK); and $20.1 \%$ receiving anticholinergics (10.3\% in France to $35.3 \%$ in Spain).

Most patients were discharged with a referral to a general practitioner (GP) (52.0\%) or were admitted to the hospital (32.3\%; Figure 4). A further $12.8 \%$ were discharged without referral to a GP, $(8.6 \%$ in Spain to $17.9 \%$ in Canada). Thirtyone patients (2.9\%) relapsed to the ED and $10(0.9 \%)$ died within 14 days after discharge from hospital. Approximately $24 \%$ of patients had been hospitalised within the six months prior to the documented ED visit.

\section{Disaussion}

This study found poor adherence with guidelines that recommend objective PFT before and during ED visits for patients with acute asthma exacerbations. PFT was performed in less than half of the patients, suggesting that many practitioners rely on subjective signs and symptoms and patient self-report rather than objective indices in order to evaluate exacerbation severity and make management decisions. This is contrary to guideline recommendations indicating that a critical component of managing asthma exacerbations and guiding treatment is the ability of physicians to judge the severity of airflow obstruction and to treat patients adequately. ${ }^{11}$ Patients treated in Australia, France, or the UK, younger patients, those with moderate exacerbations, those arriving via ambulance, and patients in university-affiliated hospitals and larger institutions were most likely to receive PFT. Pulmonologists and ED physicians were about equally likely to perform a PFT.

Patterns in the use of PFT observed in this study are consistent with published accounts. For example, a Spanish study showed that their country had the lowest proportion of HCPs conducting PFT, consistent with data from primary healthcare facilities in Spain where there was minimal adherence to guideline recommendations. ${ }^{21}$ Results of a crosssectional survey of Canadian ED physicians also showed wide variations in use of objective measurements; $46 \%$ used FEV 1 "occasionally" and $26.7 \%$ used peak flow meters "occasionally". 22 In Canada, Jin et al. found that adherence to guidelines and use of objective lung function testing were related to physician specialty, with family physicians having the lowest rates. ${ }^{23} \mathrm{~A}$ single-centre survey in Italy reported that $14 \%$ of adolescents with asthma had never had PFT performed. ${ }^{24}$ Even in specialty asthma centres in the US, spirometry is not conducted routinely. ${ }^{25}$ In this study, PEF was used more frequently than spirometry, perhaps because of ease of use and cost considerations. A standardised asthma management program in France resulted in a marked increase in PEF measurements from the first audit (19.1\%) to the postintervention audit (88.1\%, p<0.001). ${ }^{26}$ Use of spirometry or PEF increased from $38 \%$ to $85 \%(p<0.01)$ in a hospital that implemented evidence-based strategies, whereas it decreased in the control hospital. ${ }^{27}$ Effective training can be brief and inexpensive. ${ }^{28}$ Clinicians are often not trained to perform spirometry and may have been less inclined to do so, potentially leading to biased results due to underperformance. Trained clinicians may acknowledge the inadequacy of treating without the benefit of underlying pulmonary function measurement.

In the MAMBO cohort, patients who underwent PFT had significantly more courses of therapy and received more medications than those who did not undergo PFT. It may be that those clinicians who were more likely to perform objective measurements were also more likely to treat patients according to guidelines. Patients perceived to have mild disease were less likely to have PFT and patients not having PFT were less likely to receive multiple therapies, suggesting that physician perception of asthma severity may influence management. Even patients with severe disease did not routinely undergo PFT, however.

In our study, suboptimal adherence to GINA guidelines for the discharge management of acute severe asthma across a number of different countries was documented, with nearly 1 in 5 patients not receiving a prescription for an asthma medication upon ED discharge, and 1 in 8 being discharged to their communities without a follow-up physician referral. Nearly $75 \%$ of patients self-administering asthma medications shortly before visiting the ED were using SABA rescue agents, compared with only $52 \%$ using ICS alone or in combination with a LABA. This may reflect patients' increased use of bronchodilators as their asthma symptoms worsen. 
Patients in this study who had more severe exacerbations or were treated by a pulmonologist were significantly more likely to receive prescriptions for asthma medications at ED discharge, consistent with a French report showing that corticosteroid use in the ED was more likely in patients with more severe exacerbations. ${ }^{3}$ A medical audit conducted in Spain reported that $17 \%$ of patients were discharged from the ED with no change to their usual treatment and that too many patients were discharged without a treatment plan. ${ }^{29}$ Initiation of acute and chronic medications can potentially benefit patients at the time of ED discharge. ${ }^{30,31}$

Potential limitations of our study include not determining the reasons why HCPs did not perform PFT, or whether equipment for performing PFT was available at each site. Also, exclusion of HCPs involved in clinical trials may have resulted in underestimating the proportion of HCPs performing PFT. This study relied on patient self-report to assess asthma medication use within the 24 hours before ED admission, which may have skewed results towards use of therapies to alleviate acute symptoms. The study relied on HCP reports based on ED records which may not have captured accurately baseline factors such as co-morbidities, thereby potentially influencing discharge medications and instructions.

Response bias is another potential limitation. Eligible HCPs were invited to participate until target numbers were met and were therefore self-selected. We were unable to characterise participating physicians versus those who did not respond. Pre-specified quotas across specialties along with the range of countries were intended to increase the representativeness of the data. There was a low response rate in this study, but the large sample size and range of countries examined suggests the results are robust and truly reflect the current standard of acute asthma care. In addition, the study could not control for heterogeneity in the level of sub specialty training. There was also considerable variation in the healthcare systems in which patients were managed, with a higher proportion of GPS providing care in hospital ED settings and "general physicians" providing additional care for non-life-threatening asthma exacerbations in Australia.

Our findings extend previous research showing suboptimal knowledge of, adherence to, and adaptation of, asthma guidelines in general, and use of controller medications in particular, for the management of asthma in different countries. PFT was conducted infrequently in the ED setting and a substantial proportion of patients with acute exacerbations were discharged from the ED without adequate medications or referrals. There appears to be room for improvement in the care of asthma exacerbations, and in particular adherence to guidelines. Further studies are necessary to determine to what degree acute-care interventions aimed at improving asthma control help to

\section{Discussion Box}

This multinational study found poor adherence with international guidelines recommending use of pulmonary function testing and discharge management practices for patients seen in the ED for an acute asthma exacerbation. Challenges with physician recruitment, the absence of data on treatment algorithms, and limited data on pre- and post-emergent care limit the conclusions from this survey. Survey data from the patient and their GP could have helped to characterise pre- and post-emergent care. A study evaluating the impact of interventional strategies and usual care across homogeneous emergent settings would help to assess the impact of adherence to consensus guidelines on outcomes. Studies examining the drivers and barriers of objective testing, prescribing, and referral across specialties in an acute setting, are needed.

enhance patient quality of life and reduce the global burden of asthma.

\section{Funding}

This study was funded by Merck and Co Inc.

\section{Author contributions}

All authors were involved in the conception and design of the study. Drs. Demuth and Allen-Ramey were involved in the acquisition of data, and all authors were involved in the analysis and interpretation of data. The newly combined resubmitted manuscript was drafted with assistance from Wendy Horn (further details below); revising for intellectual content was conducted by all authors. All authors have read and approved the final version of the manuscript. Some of the data contained in this manuscript were presented in poster form at the 2008 American Thoracic Society Meeting, May 16-21, 2008, Toronto, Ontario, Canada.

\section{Acknowledgements}

Assistance in manuscript preparation based upon guidance and outlines from the authors, including background research, preparation of an initial draft, incorporation of author comments, as well as editing and formatting the manuscript according to journal requirements, was provided by Wendy Horn, Insight Communications Group, Westfield, NJ, USA (insightcmn@aol.com), with support from the study sponsor. Assistance in manuscript preparation was also provided by Jacki Gordon, PhD and Stephen W. Gutkin, Rete Biomedical Communications Corp, with support from the study sponsor.

\section{Conflict of interest declarations}

Dr. O'Byrne discloses that, within the past 3 years, he has served on advisory boards for AstraZeneca, Biolipox, GlaxoSmithKline (GSK), Merck, Nycomed, Topigen, Resestentia, and Wyeth; has received lecture fees form AstraZeneca, Chiesi, GSK, Nycomed, and Ono Pharma, and has been a recipient (or is a pending recipient) of grants sponsored by AstraZeneca, Altana, Boehringer, Genentech, GSK, Medimmune, Merck, Pfizer, and Wyeth.

Dr. Fitzgerald discloses that he has received fees for advisory board attendance and membership of CME lecture panels sponsored by a number of companies, including Astra Zeneca, GSK, Nycomed, Merck, and Novartis, that market drugs used in the treatment of asthma. He has also received travel assistance from GSK to attend the European Respiratory Society meeting in September 2008. He has also received research funding, for asthma-related research, from these and other pharmaceutical companies, which has been paid directly to his institution (University of British Columbia). 
Mr. McFetridge was a research fellow employed by the study sponsor at the time the study was completed.

Dr. Demuth discloses that his organisation (Adelphi Real World) was supported by the study sponsor to oversee the study, as well as to acquire data and conduct statistical analyses.

Dr. Allen-Ramey discloses that she is an employee of (and shareholder in) the study sponsor.

\section{References}

1. Tattersfield AE, Postma DS, Barnes PJ, et al. Exacerbations of asthma: a descriptive study of 425 severe exacerbations. The FACET International Study Group. Am J Respir Crit Care Med 1999;160:594-9.

2. Pauwels RA, Pedersen S, Busse WW, et al. Early intervention with budesonide in mild persistent asthma: a randomized double-blind trial. Lancet 2003;361:1071-6. http://dx.doi.org/10.1016/S0140-6736(03)12891-7

3. Salmeron S, Liard R, Elkharrat D, et al. Asthma severity and adequacy of management in accident and emergency departments in France: a prospective study. Lancet 2001;358:629-35. http://dx.doi.org/10.1016/S01406736(01)05779-8

4. Antonicelli L, Bucca $C$, Neri M, et al. Asthma severity and medical resource utilization. Eur Respir J 2004;23:723-9. http://dx.doi.org/10.1183/ 09031936.04 .00004904

5. Baren JM, Boudreaux ED, Brenner BE, et al. Randomized controlled trial of emergency department interventions to improve primary care follow-up for patients with acute asthma. Chest 2006;129(2):257-65. http://dx.doi.org/10.1378/ chest.129.2.257

6. Mannino DM, Homa DM, Pertowski CA, et al. Surveillance for asthma--United States, 1960-1995. MMWR CDC Surveill Summ 1998;47(1):1-27.

7. Murray MD, Stang P, Tierney WM. Health care use by inner-city patients with asthma. J Clin Epidemio/ 1997;50(2):167-74. http://dx.doi.org/10.1016/S08954356(96)00333-2

8. Kattan $M$, Mitchell $H$, Eggleston $P$, et al. Characteristics of inner-city children with asthma: the National Cooperative Inner-City Asthma Study. Pediatr Pulmonol 1997;24(4):253-62. http://dx.doi.org/10.1002/(SICI)10990496(199710)24:4<253::AID-PPUL4>3.0.CO;2-L

9. Halfon N, Newacheck PW. Childhood asthma and poverty: differential impacts and utilization of health services. Pediatrics 1993;91(1):56-61.

10. Griswold SK, Nordstrom CR, Clark S, Gaeta TJ, Price ML, Camargo CA, Jr. Asthma exacerbations in North American adults: who are the "frequent fliers" in the emergency department? Chest 2005;127(5):1579-86. http://dx.doi.org/10.1378/chest.127.5.1579

11. Bateman ED, Hurd SS, Barnes PJ, et al. Global strategy for asthma management and prevention: GINA executive summary. Eur Respir J 2008;31:143-78. http://dx.doi.org/10.1183/09031936.00138707

12. British Thoracic Society/Scottish Intercollegiate Guideline Network. British guidelines on the management of asthma. Thorax 2003;58(Suppl I):i1-i94.

13. Boulet LP, Becker A, Berube D, et al. Canadian Asthma Consensus Report, 1999. Canadian Asthma Consensus Group. CMAJ 1999;161(11 Suppl):S1-S61.

14. National Asthma Education and Prevention Program. Expert panel report 2. Guidelines for the diagnosis and management of asthma. Publication no. 974051. Bethesda, MD: NIH/National Heart, Lung and Blood Institute, 1997.
15. Beveridge RC, Grunfeld AF, Hodder RV, et al. Guidelines for the emergency management of asthma in adults. CMAJ 1996;155:25-37.

16. van der Molen T, Ostrem A, Stallberg B, et al. International primary care respiratory group (IPCRG) guidelines: management of asthma. Prim Care Resp J 2006;15:35-47. http://dx.doi.org/10.1016/j.pcrj.2005.11.001

17. Fitzgerald JM, Grunfeld A. Status asthmaticus. In: Lichtenstein LM, Fauci AS, eds. Current Therapy in Allergy, Immunology, and Rheumatology. 5th ed. St Louis, MO: Mosby; 1996.

18. Peters SP, Jones CA, Haselkorn T, et al. Real-world evaluation of asthma control and treatment (REACT): Findings from a national web-based survey. J Allergy Clin Immuno/ 2007;119:1454-61. http://dx.doi.org/10.1016/j.jaci.2007.03.022

19. Huffstutter J, Craig WD, Schimizzi G, et al. A multicenter, randomized, open study to evaluate the impact of an electronic data capture system on the care of patients with rheumatoid arthritis. Curr Med Res Opin 2007;23(8):1967-79.

20. Welker JA. Implementation of electronic data capture systems: barriers and solutions. Contemp Clin Trials 2007;28(3):329-36. Epub 2007 Jan 11.

21. Hueto J, Cebollero P, Pasca I, et al. Spirometry in primary care in Navarre, Spain. Arch Bronconeumol 2006;42:326-31. http://dx.doi.org/10.1016/S15792129(06)60541-7

22. Grunfeld A, Beveridge RC, Berkowitz J, FitzGerald JM. Management of acute asthma in Canada: An assessment of emergency physician behaviour. J Emerg Med 1997;15(4):547-56. http://dx.doi.org/10.1016/\$0736-4679(97)00093-0

23. Jin $\mathrm{R}$, Choi $B C$, Chan $B T$, et al. Physician asthma management practices in Canada. Can Respir J 2000;7:456-65.

24. Lombardi C, Gani F, Landi M, Boner A, Canonica GW, Passalacqua G. Clinical and therapeutic aspects of allergic asthma in adolescents. Pediatr Allerg Immunol 2003;14:453-7. http://dx.doi.org/10.1046/j.0905-6157.2003. $00080 . x$

25. Sullivan AF, Schatz M, Wenzel SE, et al. A profile of U.S. asthma centers, 2006. Ann Allergy Asthma Immunol 2007;99:419-23.

26. Chouaid C, Bal JP, Fuhrman C, et al. Standardized protocol improves asthma management in emergency department. J Asthma 2004;41:19-25. http://dx.doi.org/10.1081/JAS-120024589

27. Doherty SR, Jones PD, Davis L, et al. Evidence-based implementation of adult asthma guidelines in the emergency department: a controlled trial. Emerg Med Australas 2007;19:31-8. http://dx.doi.org/10.1111/j.1742-6723.2006. 00910.x

28. Silverman RA, Flaster E, Enight PL, Simonson SG. FEV1 performance among patients with acute asthma: results from a multicenter clinical trial. Chest 2007;131:164-71. http://dx.doi.org/10.1378/chest.06-0530

29. Linares T, Campos A, Torres M, Reyes J. Medical audit on asthma in an emergency department. Immunopathol (Madr) 2006;34(6):248-51. http://dx.doi.org/10.1157/13095872

30. Singer AJ, Camargo CA, Lampell M, et al. A call for expanding the role of the emergency physician in the care of patients with asthma. Annals of Emerg Med 2005;45(3):295-8. http://dx.doi.org/10.1016/j.annemergmed. 2004.09.024

31. Singh AK, Woodruff PG, Ritz RH, et al. Inhaled corticosteroids for asthma: Are ED visits a missed opportunity for prevention? Am J Emerg Med 1999;17: 144-7. http://dx.doi.org/10.1016/S0735-6757(99)90047-5

\section{Available online at http://www.thepaj.org}


PFT and discharge medication for asthma in the ED

Appendix: Multinational Acute Asthma Management, Burden, and Outcomes (MAMBO) Study: Internet Questionnaire Answered by Physicians

Patient Questions

Patient Demographics (PD)

PD1. What is the patient's age?

15-19 years

20-29 years

30-39 years

40-49 years

50-59 years

60-70 years

PD2. What is the patient's gender?

Male

Female

PD3. What asthma admission code (either an ICD-9 or ICD-10 code) was assigned to the patient on their arrival into hospital?

(Please specify) $\quad x$ Information not available

Please also specify the severity of the acute asthma exacerbation on the patients arrival into hospital.

- Mild

- Moderate

- Severe

- Information not available

PD4. Does the patient have medical insurance?

- Yes, the patient has insurance

- No, the patient is uninsured

- Information not available 
JM Fitzgerald et al.

PD5. Does the patient smoke?

-Yes

- No

- Information not available

PD6. Please indicate any concomitant conditions that were recorded for the patient at time of the emergency asthma admission:

Please tick all that apply

- Atrial Fibrillation

- Angina Pectoris

- Arrhythmias

- Congestive Heart Failure

- Post-myocardial Infarction

- Anxiety

- Allergic Dermatitis

- Chronic Obstructive Pulmonary Disease (COPD)

- Community Acquired Pneumonia (CAP)

- Depression

- Obesity

- Viral Infection

- Seasonal Rhinitis

- Perennial Rhinitis

- Other condition specifically relevant to the management of this patient's asthma (please specify)

- Other condition specifically relevant to the management of this patient's asthma (please specify)

- Other condition specifically relevant to the management of this patient's asthma (please specify)

- None

- Information not available 
PFT and discharge medication for asthma in the ED

\section{$\underline{\text { Staff attending the emergency asthma admission }}$}

RU1. Approximately how many hours did the patient spend in the emergency department (or equivalent) for their acute asthma exacerbation? This does not include subsequent hospital admission and continuing care.

Please round up to the nearest hour, greater than 0 hours (please specify)

RU2. During the time the patient was treated what staff were involved in the patient's treatment?

Please include yourself in this question and consider only the primary specialty of all the physicians involved.

Please tick all that apply.

- Emergency department (ED) physician (this assumes that the physician is primarily trained in emergency medicine)

- Internist

- Pulmonologist/ Chest physician

- Urgentist (France only)

- Nurse

- General Practitioner (Canada only)

- General Practitioner/ General Physician (Outsourced) (Australia only)

- Other (please specify)

- Other (please specify)

- Other (please specify)

- Information not available

\section{Lung Function and Blood Saturation Tests}

LU1. Were any lung function tests performed on the patient during their acute asthma episode in the emergency department (or equivalent)? Please indicate all that apply.

- Peak Expiratory Flow (PEF) - Go to LU2

- Forced Expiratory Volume (FEV) 1 - Go to LU2.

- No lung function tests performed - Go to LU3 
JM Fitzgerald et al.

LU2.1 Please indicate the actual value and \% predicted value obtained using Peak Expiratory Flow (PEF), as soon as the patient entered the emergency department (or equivalent) for their acute asthma episode. Please also provide any additional information on subsequent tests performed during the patient's time in the emergency department (or equivalent) for their acute asthma episode.

\begin{tabular}{|c|c|c|}
\hline & PEF actual value & PEF \% predicted value \\
\hline $\begin{array}{l}\text { Test } 1 . \\
\text { As soon as the patient } \\
\text { entered the emergency } \\
\text { department (or equivalent) } \\
\text { for their acute asthma } \\
\text { episode. }\end{array}$ & $\begin{array}{l}\text { Litres } \\
\text { - Inin } \\
\text { available }\end{array}$ & - Information not available \\
\hline Test 2. & $\begin{array}{l}\text { Litres } \\
\text { - Information not } \\
\text { available }\end{array}$ & - Information not available \\
\hline Test 3. & $\begin{array}{l}\text { Litres } \\
\text { - Ininformation not } \\
\text { available }\end{array}$ & $\begin{array}{l}\text { \% predicted } \\
\text { - Information not available }\end{array}$ \\
\hline Test 4. & $\begin{array}{l}\text { Litres } \\
\text { - Information not } \\
\text { available }\end{array}$ & $\begin{array}{l}\text { \% predicted } \\
\text { - Information not available }\end{array}$ \\
\hline Test 5. & $\begin{array}{l}\text { Litres } \\
7 \text { Information not } \\
\text { available }\end{array}$ & $\begin{array}{l}\% \text { predicted } \\
7 \text { Information not available }\end{array}$ \\
\hline Test 6. & $\overline{\text { Litres }}$ & $\begin{array}{l}\text { \% predicted } \\
\text { Range } 1-100 \%\end{array}$ \\
\hline
\end{tabular}


PFT and discharge medication for asthma in the ED

\begin{tabular}{|l|l|l|}
\hline & PN - Range 1-999 & - Information not available \\
- Information not & \\
available & \\
\hline
\end{tabular}


LU2.2 Please indicate the actual value and \% predicted value obtained using Forced Expiratory Volume $(\mathrm{FEV})_{1}$, as soon as the patient entered the emergency department (or equivalent) for their acute asthma episode. Please also provide any additional information on subsequent tests performed during the patient's time in the emergency department (or equivalent) for their acute asthma episode.

\begin{tabular}{|c|c|c|}
\hline & $\mathrm{FEV}_{1}$ actual value & $\mathrm{FEV}_{1} \%$ predicted value \\
\hline $\begin{array}{l}\text { Test } 1 . \\
\text { As soon as the patient entered } \\
\text { the emergency department (or } \\
\text { equivalent) for their acute } \\
\text { asthma episode. }\end{array}$ & $\begin{array}{l}\text { Litres /min } \\
\text { - Information not available }\end{array}$ & - Information not available \\
\hline Test 2. & $\begin{array}{l}\text { Litres /min } \\
\text { - Information not available }\end{array}$ & $\begin{array}{l}\% \text { predicted } \\
\text { - Information not available }\end{array}$ \\
\hline Test 3. & $\begin{array}{l}\text { Litres /min } \\
\text { - Information not available }\end{array}$ & $\begin{array}{l}\% \text { predicted } \\
\text { - Information not available }\end{array}$ \\
\hline Test 4. & $\begin{array}{l}\text { Litres /min } \\
\text { - Information not available }\end{array}$ & $\begin{array}{l}\text { \% predicted } \\
\text { - Information not available }\end{array}$ \\
\hline Test 5. & $\begin{array}{l}\text { Litres /min } \\
\text { - Information not available }\end{array}$ & $\begin{array}{l}\% \text { predicted } \\
\text { - Information not available }\end{array}$ \\
\hline Test 6. & $\begin{array}{l}\text { Litres /min } \\
\text { - Information not available }\end{array}$ & $\begin{array}{l}\% \text { predicted } \\
\text { - Information not available }\end{array}$ \\
\hline
\end{tabular}

LU3. Were any arterial blood gas measurements taken from the patient during their acute asthma episode in the emergency department (or equivalent)?

Please indicate all that apply.

- $\mathrm{PaO}_{2}-\mathrm{Go}$ to LU4.1

- $\mathrm{PaCO}_{2}$ - Go to LU4.2

- No arterial blood gas measurements taken - Go to next section (DU1A) 
PFT and discharge medication for asthma in the ED

LU4.1 Please indicate the $\mathrm{PaO}_{2}$ obtained as soon as the patient entered the emergency department (or equivalent) for their acute asthma episode. Please also provide any additional information on subsequent measurements taken during the patient's time in the emergency department (or equivalent) for their acute asthma episode.

\begin{tabular}{|c|c|}
\hline & $\mathrm{PaO}_{2}$ \\
\hline $\begin{array}{l}\text { Test } 1 . \\
\text { As soon as the patient entered the } \\
\text { emergency department (or equivalent) } \\
\text { for their acute asthma episode. }\end{array}$ & $\begin{array}{c}\mathrm{mmHg} \\
\text { - information not available }\end{array}$ \\
\hline Test 2. & $\begin{array}{l}\mathrm{mmHg} \\
\text { - information not available }\end{array}$ \\
\hline Test 3. & $\begin{array}{l}\mathrm{mmHg} \\
\text { - information not available }\end{array}$ \\
\hline Test 4. & - information not available \\
\hline Test 5. & $\begin{array}{l}\mathrm{mmHg}_{\mathrm{kPa}} \\
\text { - information not available }\end{array}$ \\
\hline Test 6. & $\begin{array}{c}\text { mmHg } \\
\text { - information not available }\end{array}$ \\
\hline
\end{tabular}


JM Fitzgerald et al.

LU4.2 Please indicate the $\mathrm{PaCO}_{2}$ measurements obtained as soon as the patient entered the emergency department (or equivalent) for their acute asthma episode. Please also provide any additional information on subsequent measurements taken during the patient's time in the emergency department (or equivalent) for their acute asthma episode.

\begin{tabular}{|c|c|}
\hline & $\mathrm{PaCO}_{2}$ \\
\hline $\begin{array}{l}\text { Test } 1 . \\
\text { As soon as the patient entered the } \\
\text { emergency department (or equivalent) } \\
\text { for their acute asthma episode. }\end{array}$ & $\begin{array}{l}\ldots \mathrm{mmHg} \\
\text { - information not available }\end{array}$ \\
\hline Test 2. & $\begin{array}{c}\mathrm{mmHg} \\
\text { - information not available }\end{array}$ \\
\hline Test 3. & $\begin{array}{l}\mathrm{mmHg} \\
\mathrm{kPa} \\
\text { - information not available }\end{array}$ \\
\hline Test 4. & ${ }_{\text {-information not available }}^{\mathrm{mmHg}}$ \\
\hline Test 5. & $\begin{array}{l}\mathrm{mmHg}^{\mathrm{kPa}} \\
\text { - information not available }\end{array}$ \\
\hline
\end{tabular}




\section{Drug Usage (DU)}

DU1a. What asthma-specific medication (including oxygen) did the patient receive to treat their emergency asthma exacerbation?

Please indicate if medication was received in the emergency department (or equivalent), the ambulance or was prescribed by a general practitioner immediately prior to the patient entering the emergency department (or equivalent).

\begin{tabular}{|c|c|}
\hline Drug Class & Please tick all that apply \\
\hline Anti-cholinergic & $\begin{array}{l}\text { - emergency department (or equivalent) } \\
\text { - ambulance } \\
\text {-general practitioner }\end{array}$ \\
\hline Corticosteroids & $\begin{array}{l}\text { - emergency department (or equivalent) } \\
\text { - ambulance } \\
\text { - general practitioner }\end{array}$ \\
\hline Inhaled Corticosteroids & $\begin{array}{l}\text { - emergency department (or equivalent) } \\
\text { - ambulance } \\
\text { - general practitioner }\end{array}$ \\
\hline Long Acting $\beta$ agonist (LABA) & $\begin{array}{l}\text { - emergency department (or equivalent) } \\
\text { - ambulance } \\
\text { - general practitioner }\end{array}$ \\
\hline Short Acting $\beta$ agonist (SABA) & $\begin{array}{l}\text { - emergency department (or equivalent) } \\
\text { - ambulance } \\
\text { - general practitioner }\end{array}$ \\
\hline $\begin{array}{l}\text { Inhaled Corticosteroid (ICS)/ } \\
\text { Long Acting } \beta \text { agonist (LABA) } \\
\text { combined product }\end{array}$ & $\begin{array}{l}\text { - emergency department (or equivalent) } \\
\text { - ambulance } \\
\text { - general practitioner }\end{array}$ \\
\hline Leukotreine antagonists & $\begin{array}{l}\text { - emergency department (or equivalent) } \\
\text { - ambulance } \\
\text { - general practitioner }\end{array}$ \\
\hline Cromolyns & $\begin{array}{l}\text { - emergency department (or equivalent) } \\
\text { - ambulance } \\
\text { - general practitioner }\end{array}$ \\
\hline Theophyllines & $\begin{array}{l}\text { - emergency department (or equivalent) } \\
\text { - ambulance } \\
\text { - general practitioner }\end{array}$ \\
\hline
\end{tabular}




\begin{tabular}{|l|l|}
\hline Oxygen (PN Range 1-100_ emergency department (or equivalent) \% \\
(please specify the percentage of Oxygen) \\
- ambulance \% (please specify the \\
percentage of Oxygen) \\
- general practitioner \% (please specify the \\
percentage of Oxygen)
\end{tabular}

Information not available $\quad$ - SKIP TO DU2

DU1b. With respect to the medication only received by the patient in the ambulance or prescribed by a general practitioner immediately prior to the patient entering the hospital, please select the Method of Delivery and write in the dosage and the frequency that the medication was delivered to the patient during the acute asthma episode.

\begin{tabular}{|l|l|l|l|l|l|}
\hline Drug Class & $\begin{array}{l}\text { Method of } \\
\text { Delivery }\end{array}$ & Dosage: & $\begin{array}{l}\text { Dosage } \\
\text { Units }\end{array}$ & $\begin{array}{l}\text { Dosage } \\
\text { Units }\end{array}$ & $\begin{array}{l}\text { Frequency (Number } \\
\text { of times medication } \\
\text { administered) in the } \\
\text { ambulance or } \\
\text { prescribed by a } \\
\text { general practitioner }\end{array}$ \\
\hline Anti-cholinergic & $\begin{array}{l}\text { FOR ALL } \\
\text { (drop-down } \\
\text { box })\end{array}$ & $\begin{array}{l}\text { FOR ALL } \\
\text { (drop- } \\
\text { down }\end{array}$ & $\begin{array}{l}\text { FOR ALL } \\
\text { (drop- } \\
\text { down }\end{array}$ & \\
\hline
\end{tabular}


PFT and discharge medication for asthma in the ED

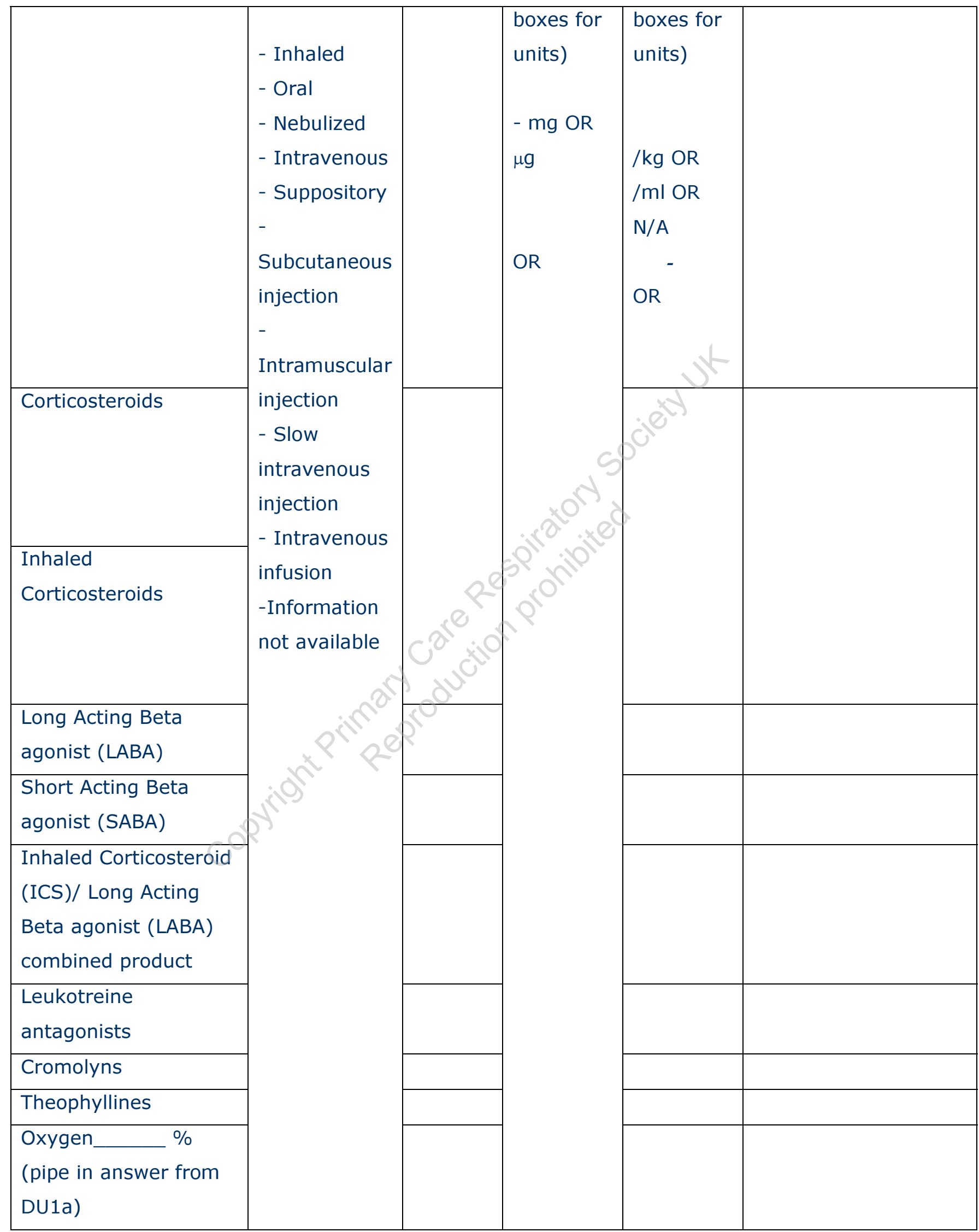


JM Fitzgerald et al.

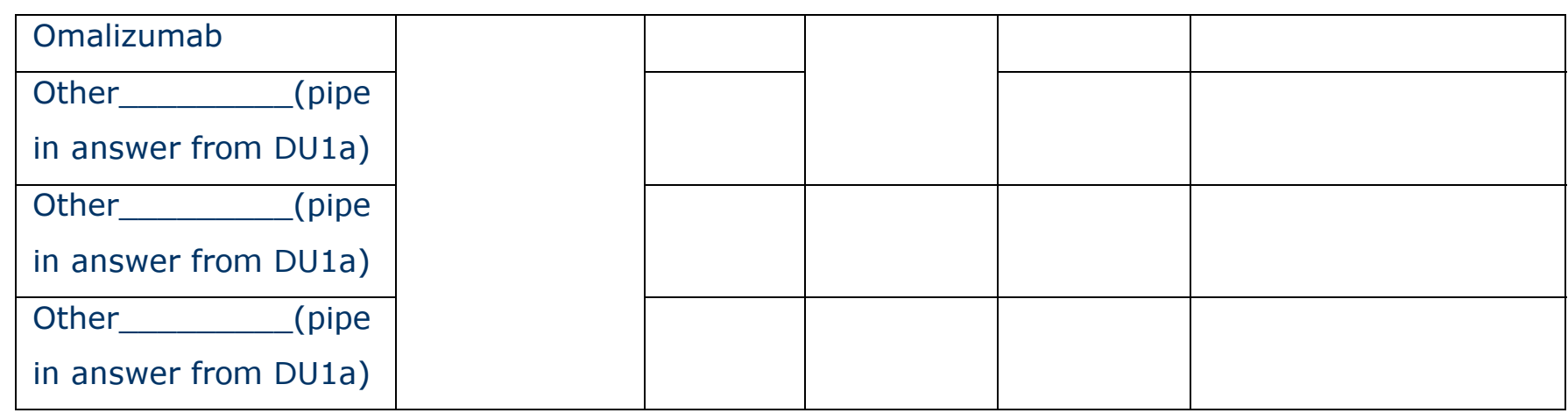

DU1C. Please indicate how many rounds of drug therapy the patient received in the emergency department (or equivalent) (a round is defined as one or more medications given concurrently to the patient within a short space of time).

DU1d. For the $\left[1^{\text {st }}\right.$ - change accordingly, $\left.2^{\text {nd }}, 3^{\text {rd }} \ldots\right]$ round of drug therapy, please indicate the medication prescribed and the Method of Delivery. Please also write in the dosage of the medication that was delivered to the patient in the emergency department (or equivalent) during the acute asthma episode.

Note: This question was repeated as necessary depending on the number of times indicated in item DU1c and for drugs coded as emergency department (or equivalent) in DU1a

When writing the dosage, if the information is unavailable, please tick 'DK' for Don't know

When selecting the dosage units, you will see that there are two drop down lists due to the different types of dosage units that you might need to select. You may only need to select the units in one of these drop down lists.

If Oxygen was used please only tick if it was used or not.

\begin{tabular}{|l|l|l|l|l|}
\hline Drug Class & $\begin{array}{l}\text { Method of } \\
\text { Delivery }\end{array}$ & Dosage: & Dosage Units & $\begin{array}{l}\text { Dosage } \\
\text { Units }\end{array}$ \\
\hline - Anti-cholinergic & $\begin{array}{l}\text { FOR ALL } \\
\text { (drop-down } \\
\text { box) }\end{array}$ & & $\begin{array}{l}\text { FOR ALL } \\
\text { (drop-down } \\
\text { boxes for } \\
\text { units) }\end{array}$ & $\begin{array}{l}\text { FOR ALL } \\
\text { (drop-down } \\
\text { boxes for } \\
\text { units) }\end{array}$ \\
\hline
\end{tabular}


PFT and discharge medication for asthma in the ED

\begin{tabular}{|l|l|l|l|l|}
\hline & $\begin{array}{l}\text { - Inhaled } \\
\text { - Oral } \\
\text { - Nebulized } \\
\text { - Intravenous } \\
\text { - Suppository }\end{array}$ & & \multirow{2}{*}{ - mg OR $\mu \mathrm{g}$} & \\
\cline { 1 - 1 } & - & & / $\mathrm{kg}$ OR /mI \\
OR N/A
\end{tabular}


JM Fitzgerald et al.

\begin{tabular}{|c|}
\hline in answer from DU1a) \\
\hline $\begin{array}{l}\text {-Other__(pipe } \\
\text { in answer from DU1a) }\end{array}$ \\
\hline
\end{tabular}

DU2. Was the patient prescribed any other non-asthma related medications at the time of the asthma exacerbation?

- Yes - Go to question DU3

- No - Go to question DU4

- Information not available - Go to question DU4

DU3. For each of the non-asthma related medications, please indicate the name of the drug, the method of delivery, the dosage prescribed and the frequency. Please include only the generic drug name, if possible.

\begin{tabular}{|c|c|c|c|c|c|}
\hline Drug Class & Method of Delivery & Dosage: & $\begin{array}{l}\text { Dosage } \\
\text { Units }\end{array}$ & $\begin{array}{l}\text { Dosage } \\
\text { Units }\end{array}$ & $\begin{array}{l}\text { Frequency } \\
\text { (Number of times } \\
\text { medication } \\
\text { administered in } \\
\text { the ED (or } \\
\text { equivalent)) }\end{array}$ \\
\hline $\begin{array}{l}\text { Other } \\
\text { (please specify) }\end{array}$ & \multirow{6}{*}{$\begin{array}{l}\text { - Inhaled } \\
\text { - Oral } \\
\text { - Nebulized } \\
\text { - Intravenous } \\
\text { - Suppository } \\
\text { - Subcutaneous } \\
\text { injection } \\
\text { - Intramuscular } \\
\text { injection } \\
\text { - Slow intravenous } \\
\text { injection } \\
\text { - Intravenous } \\
\text { infusion } \\
\text {-Information not } \\
\text { available }\end{array}$} & & \multirow{6}{*}{$\begin{array}{l}\text { FOR ALL } \\
\text { (drop- } \\
\text { down } \\
\text { boxes for } \\
\text { units) }\end{array}$} & \multirow{6}{*}{$\begin{array}{l}\text { FOR ALL } \\
\text { (drop- } \\
\text { down } \\
\text { boxes for } \\
\text { units) }\end{array}$} & \\
\hline $\begin{array}{l}\text { Other } \\
\text { (please specify) }\end{array}$ & & & & & \\
\hline $\begin{array}{l}\text { Other } \\
\text { (please specify) }\end{array}$ & & & & & \\
\hline $\begin{array}{l}\text { Other } \\
\text { (please specify) }\end{array}$ & & & & & \\
\hline $\begin{array}{l}\text { Other } \\
\text { (please specify) }\end{array}$ & & & & & \\
\hline & & & & & \\
\hline
\end{tabular}


PFT and discharge medication for asthma in the ED

DU4. Did the patient self-administer any asthma medication during the 24 hours immediately prior to them entering the emergency department (or equivalent) (this does not include medication received in the ambulance or by a general practitioner, if applicable)?

- Yes - Go to question DU5

- No - Go to question DU6

- Information not available - Go to question DU6

DU5. Please indicate any asthma-related medication the patient self-administered during the 24 hours immediately prior to them entering the emergency department (or equivalent).

\begin{tabular}{|c|c|}
\hline Drug Class & Please tick all that apply \\
\hline Anti-cholinergic & - \\
\hline Corticosteroids & - \\
\hline Inhaled Corticosteroids & - \\
\hline $\begin{array}{l}\text { Long Acting Beta } \\
\text { agonist (LABA) }\end{array}$ & - \\
\hline $\begin{array}{l}\text { Short Acting Beta } \\
\text { agonist (SABA) }\end{array}$ & - \\
\hline $\begin{array}{l}\text { Inhaled Corticosteroid } \\
\text { (ICS)/ Long Acting } \\
\text { Beta agonist (LABA) } \\
\text { combined product }\end{array}$ & $0 \%$ \\
\hline Leukotreine antagonists & - \\
\hline Cromolynes & - \\
\hline Theophyllines & - \\
\hline $\begin{array}{l}\text { Oxygen__ } \% \\
\text { (please specify PN } \\
\text { RANGE 1-100) }\end{array}$ & - \\
\hline Omalizumab & - \\
\hline $\begin{array}{l}\text { Other____ (please } \\
\text { specify) }\end{array}$ & - \\
\hline
\end{tabular}

Information not available 
JM Fitzgerald et al.

DU6. Was the patient prescribed any asthma medication to take home?

Yes - Go to question DU7

No - Go to question next section i.e PO1

Information not available - Go to next section i.e PO1

DU7. Please indicate the medication the patient was prescribed to take home.

\begin{tabular}{|l|l|}
\hline Drug Class & Please tick all that apply \\
\hline Anti-cholinergic & - \\
\hline Corticosteroids & - \\
\hline Inhaled Corticosteroids & - \\
\hline $\begin{array}{l}\text { Long Acting } \beta \text { agonist } \\
\text { (LABA) }\end{array}$ & - \\
\hline $\begin{array}{l}\text { Short Acting } \beta \text { agonist } \\
\text { (SABA) }\end{array}$ & - \\
\hline $\begin{array}{l}\text { Inhaled Corticosteroid } \\
\text { (ICS)/ Long Acting } \beta \\
\text { agonist (LABA) } \\
\text { combined product }\end{array}$ & - \\
\hline Leukotreine antagonists & - \\
\hline Cromolynes & - \\
\hline Theophyllines & - \\
\hline $\begin{array}{l}\text { Oxygen_ } \\
\text { (please specify PN - } \\
\text { RANGE 1-100) }\end{array}$ & - \\
\hline Omalizumab & - \\
\hline $\begin{array}{l}\text { Other__ease } \\
\text { specify) }\end{array}$ & - \\
\hline
\end{tabular}

Information not available 


\section{Patient Outcome (PO)}

PO1. What was the outcome of the patient?

- Admitted to hospital for further observation and/or treatment (Go to question PO2)

- Discharged to the community with referral to general/ family practitioner (Go to PO4)

- Discharged to the community with no referral (Go to PO4)

- Death (Go to PO5)

- Information not available (Go to PO4)

PO2. Where was the patient admitted?

- Intensive/ critical care

- Ward based care

- Information not available

PO3. Approximately how many days in total did the patient remain in hospital?

Please round up to the nearest full day, greater than 0

- __ days (Please write in)

- Information not available

PO4. Was the patient re-admitted within 14 days of initial discharge for a similar acute asthma exacerbation?

- Yes

- No

- Information not available

P05. How many times has the patient entered the hospital in the last 6 months, for a similar acute asthma exacerbation?

Please include the current hospital visit in your answer. (please specify)

- Information not available 
JM Fitzgerald et al.

\section{Physician Questions}

\section{Physician Demographics}

D.1 In addition to your primary speciality, do you have any specific training or licence in emergency medicine?

\section{Yes}

No

Not applicable

D.2 In what year did you qualify as a doctor?

Before 1969

$1970-1979$

$1980-1989$

$1990-1999$

$1999+$

D.3 What is your gender?

Male

Female

D.4 What is your age?

$$
\begin{aligned}
& \text { 25-29 years } \\
& 30-34 \text { years } \\
& 35-39 \text { years } \\
& \text { 40-49 years } \\
& 50-59 \text { years } \\
& 60+\text { years }
\end{aligned}
$$

D.5 What is the type of hospital you work at?

Please tick the most applicable description.

- University (linked to a university and acts as a teaching hospital);

- Regional or state specialist hospital (may specialise in specific diseases or age [e.g. paediatric hospital] and serves a larger region outside of the area in which it is situated)

- General hospital (serving a town or part of a city) 
PFT and discharge medication for asthma in the ED

- Local hospital (serving a small town)

- Emergency clinic (for ambulatory patients only)

- Other (please specify)

D. 6 What is the size of the hospital you work in?

Please tick the most applicable description

- Less than 300 beds

- 301-500 beds

- 501-1000 beds

- 1001+ beds

- Don't know

D.7 Is your hospital positioned in a rural or urban area?

Rural

Urban

D.8. In which region is your hospital based?

\begin{tabular}{|l|l|l|l|}
\hline Italy & France & Skain \\
[1] Abruzzo & [1] Alsace & [1] Andalucía & [1] London / \\
[2] Basilicata & [2] Aquitaine & [2] Aragón & South [2] East \\
[3] Calabria & [3] Auvergne & [3] Asturias & [3] South West \\
[4] Campania & [4] Basse- & [4] Baleares & [4] Midlands \\
[5] Emilia & Normandie & [5] Canarias & [5] Yorkshire / \\
Romagna & [5] Bourgogne & [6] Cantabria & North East \\
[6] Friuli Venezia & [6] Bretagne & [7] Castilla y León & [6] North West \\
Giulia & [7] Centre & [8] Castilla-La & [7] East \\
[7] Lazio & [8] Champagne- & Mancha & [8] Scotland \\
[8] Liguria & Ardenne & [9] Cataluña & [9] Northern \\
[9] Lombardia & [9] Corse & [10] Ceuta y & Ireland \\
[10] Marche & [10] Franche- & Melilla & [10] Wales \\
[11] Molise & Comté & [11] Comunidad & \\
[12] Piemonte & [11] Haute & Valenciana & \\
\hline
\end{tabular}


JM Fitzgerald et al.

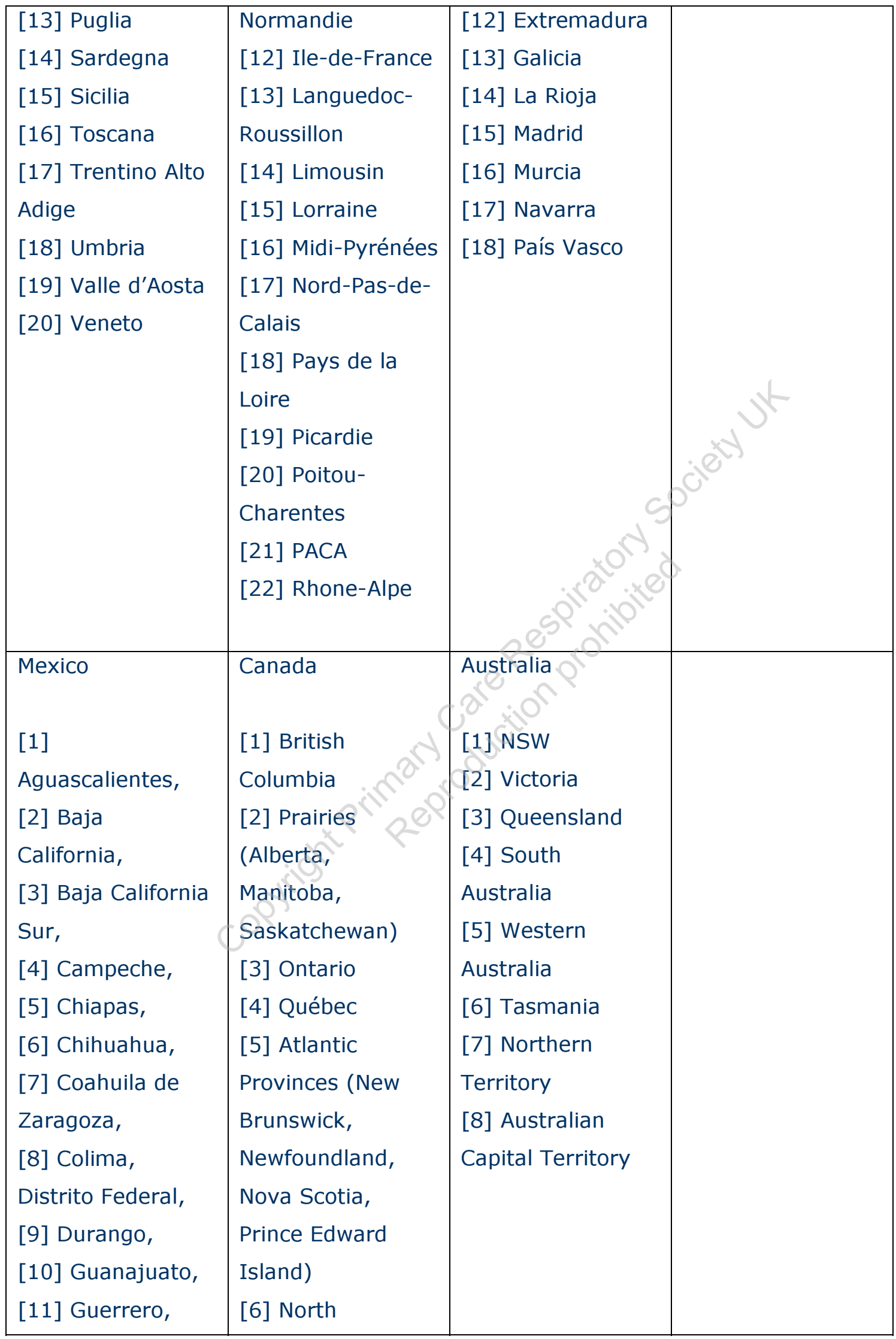


PFT and discharge medication for asthma in the ED

\begin{tabular}{|l|l|l|l|}
\hline [12] Hidalgo, & (Northwest & & \\
[13] Jalisco, & Territories, & \\
[14] Mexico, & Nunavut, Yukon) & & \\
[15] Michoacan de & & \\
Ocampo, & & \\
[16] Morelos, & \\
[17] Nayarit, & \\
[18] Nuevo Leon, & \\
[19] Oaxaca, \\
[20] Puebla, \\
[21] Queretaro de
\end{tabular}

D.9 Does your hospital have an emergency department?

- Yes

- No 
JM Fitzgerald et al.

D.10 What is the usual pathway of care for an emergency asthma patient in your hospital?

- Always treat in the emergency department as first point of care

- Sometimes treat in the emergency department or patient can be treated on a hospital ward as point of first care

- Never treat in the emergency department, the patient goes straight to the hospital ward for treatment

D.11 Where do you treat emergency asthma patients?

You may select all that apply.

- The emergency department

- The general hospital ward

- $\quad$ Specialist ward (e.g. pulmonary ward) 